\title{
JBIR-14, a highly oxygenated ergostane, from Isaria sp. NBRC 104353
}

\author{
Jun-ya Ueda ${ }^{1}$, Tatsuki Kunoh ${ }^{2}$, Masayuki Sekigawa ${ }^{2}$, Shu-ichi $\mathrm{Wada}^{2}$, Yukio Mukai ${ }^{2}$ Shinji Ohta ${ }^{2}$, \\ Ryuzo Sasaki ${ }^{3}$, Tamio Mizukami ${ }^{2}$, Motoki Takagi ${ }^{1}$ and Kazuo Shin-ya ${ }^{4}$
}

The Journal of Antibiotics (2010) 63, 139-141; doi:10.1038/ja.2010.3; published online 22 January 2010

Keywords: dynAP; ergostane; Isaria sp.; Mad2; yeast

Many proteins linked with accelerated proliferation of human cancer cells repress the growth of yeast. ${ }^{1-3}$ The inhibitors of these human proteins can restore the inhibition of yeast proliferation with these human proteins, such as Cdk4, PTEN and poly(ADP-ribose) polymerase; ${ }^{4}$ therefore, these observations have led to the development of a cell-based high-throughput screening system for anticancer drugs. Our group has revealed that a previously uncharacterized protein, termed dynAP (dynactin-associating protein), inhibits the growth of a mutant budding yeast lacking Mad2, a principal component of mitotic checkpoint, but does not affect the growth of wild-type yeast. ${ }^{5}$ DynAP is localized in Golgi and plasma membrane and interacts with dynactin components; it thus forms a complex and acts as a minus end-directed microtubule motor. Furthermore, dynAP expresses in approximately $50 \%$ of human cancer cell lines, contrary to its lowlevel expression in normal cells. Thus, dynAP could be a new target of anticancer drug discovery.

Inhibitors of dynAP could be discovered by monitoring the restoration of dynAP-induced growth inhibition of the mutant yeast lacking Mad2. In the course of our screening program for inhibitors of dynAP, the culture extract of an entomopathogenic fungus, Isaria sp. NBRC 104353, exhibited the restoration of dynAP-induced growth inhibition. We isolated a new steroidal compound, named JBIR-14 (1), by activity-guided isolation from the culture extract of Isaria sp. NBRC 104353 (Figure 1a). We report herein the fermentation, isolation and structure elucidation of 1 .

Isaria sp. NBRC 104353, purchased from the National Institute of Technology and Evaluation (Tokyo, Japan), was cultivated in $50 \mathrm{ml}$ test tubes containing $15 \mathrm{ml}$ of potato dextrose broth $\left(24 \mathrm{gl}^{-1}\right.$ potato dextrose; BD Biosciences, San Jose, CA, USA). The test tubes were shaken in a reciprocal shaker ( 355 r.p.m.) at $27^{\circ} \mathrm{C}$ for 3 days. Aliquots $(1 \mathrm{ml})$ of the culture were transferred to $100 \mathrm{ml}$ Erlenmeyer flasks containing a medium consisting of $3 \mathrm{~g}$ oatmeal (Quaker, Chicago, IL, USA) and $10 \mathrm{ml} \mathrm{V8} \mathrm{Mix} \mathrm{Juice} \mathrm{(Campbell} \mathrm{Soup} \mathrm{Company,} \mathrm{Camden,}$ NJ, USA) and were incubated in static culture at $27^{\circ} \mathrm{C}$ for 14 days.

The culture (20 flasks) was extracted with $80 \%$ aq. $\mathrm{Me}_{2} \mathrm{CO}$. After concentration in vacuo, the aqueous concentrate was extracted with EtOAc $(100 \mathrm{ml} \times 3)$. The organic layer was dried over $\mathrm{Na}_{2} \mathrm{SO}_{4}$ and then evaporated to dryness. The dried residue $(0.58 \mathrm{~g})$ was subjected to normal-phase medium-pressure liquid chromatography (MPLC; Purif-Pack SI $60 \mu \mathrm{m}$, size: $60(26.5$ i.d. $\times 100 \mathrm{~mm})$, Moritex, Tokyo, Japan) and eluted with a stepwise system of $n$-hexane-EtOAc and $\mathrm{CHCl}_{3}-\mathrm{MeOH}$, successively, to yield an active fraction $(73.0 \mathrm{mg})$ in $\mathrm{CHCl}_{3}-\mathrm{MeOH}$ (19:1) eluate. The active fraction was rechromatographed on the normal-phase column (Purif-Pack SI $60 \mu \mathrm{m}$, size: 20 (20 i.d. $\times 60 \mathrm{~mm}$ ) with $\mathrm{CHCl}_{3}-\mathrm{MeOH}$ (99:1, 49:1, successively). Finally, the active fraction $(9.5 \mathrm{mg}$ ) was purified by preparative reverse-phase HPLC using a Senshu Pak PEGASIL ODS column (20 i.d. $\times 150 \mathrm{~mm}$; Senshu Scientific, Tokyo, Japan) developed with $80 \%$ $\mathrm{MeOH}-\mathrm{H}_{2} \mathrm{O}$ including $0.1 \%$ formic acid (flow rate: $10 \mathrm{ml} \mathrm{min}^{-1}$ ) to yield 1 (3.4 $\mathrm{mg}$, retention time $19.7 \mathrm{~min}$ ).

Compound $\mathbf{1}$ was obtained as a colorless amorphous solid $\left([\alpha]^{24}{ }_{\mathrm{D}}+4.0^{\circ}, c 0.12\right.$, in $\mathrm{MeOH}$; UV $\lambda_{\max } 240 \mathrm{~nm}$, sh, in $\left.\mathrm{MeOH}\right)$ and its molecular formula was determined to be $\mathrm{C}_{28} \mathrm{H}_{42} \mathrm{O}_{6}$ by HRelectrospray ionization-MS $\left(\mathrm{m} / z \quad 475.3078 \quad[\mathrm{M}+\mathrm{H}]^{+}\right.$, calcd for $\left.\mathrm{C}_{28} \mathrm{H}_{43} \mathrm{O}_{6}, 475.3060\right)$. The IR $\left(v_{\max } 1714 \mathrm{~cm}^{1}\right)$ spectra of 1 suggested the presence of a carbonyl group. The direct connectivity between each proton and carbon was established by a heteronuclear single-quantum coherence spectrum. The ${ }^{13} \mathrm{C}$ and ${ }^{1} \mathrm{H}$ NMR spectral data for $\mathbf{1}$ are shown in Table 1. NMR spectra show 28 signals, including six methyl signals $\left(\mathrm{C}-18, \delta_{\mathrm{C}} 20.13, \delta_{\mathrm{H}} 1.37\right.$; $\mathrm{C}-19, \delta_{\mathrm{C}} 18.2, \delta_{\mathrm{H}} 0.89$; $\mathrm{C}-21, \delta_{\mathrm{C}} 17.6, \delta_{\mathrm{H}} 1.18 ; \mathrm{C}-26, \delta_{\mathrm{C}} 20.07, \delta_{\mathrm{H}} 0.98 ; \mathrm{C}-27, \delta_{\mathrm{C}} 18.1, \delta_{\mathrm{H}} 0.94$; $\left.\mathrm{C}-28, \delta_{\mathrm{C}} 12.7, \delta_{\mathrm{H}} 0.96\right)$. Four partial structures were established by a

\footnotetext{
${ }^{1}$ Biomedicinal Information Research Center, Japan Biological Informatics Consortium (JBIC), Aomi, Koto-ku, Tokyo, Japan; ${ }^{2}$ Nagahama Institute of Bio-Science and Technology, Tamura-cho, Nagahama-shi, Shiga, Japan; ${ }^{3}$ Frontier Pharma, Tamura-cho, Nagahama-shi, Shiga, Japan and ${ }^{4}$ Biomedicinal Information Research Center, National Institute of Advanced Industrial Science and Technology, Aomi, Koto-ku, Tokyo, Japan

Correspondence: Dr K Shin-ya, Biomedicinal Information Research Center (BIRC), National Institute of Advanced Industrial Science and Technology (AIST), 2-4-7 Aomi, Koto-ku, Tokyo 135-0064, Japan. E-mail: k-shinya@aist.go.jp or Dr M Takagi, Biomedicinal Information Research Center (BIRC), Japan Biological Informatics Consortium (JBIC), 2-4-7 Aomi, Koto-ku, Tokyo 135-0064, Japan.

E-mail: motoki-takagi@aist.go.jp
}

Received 10 November 2009; revised 4 January 2009; accepted 6 January 2009; published online 22 January 2010 
a

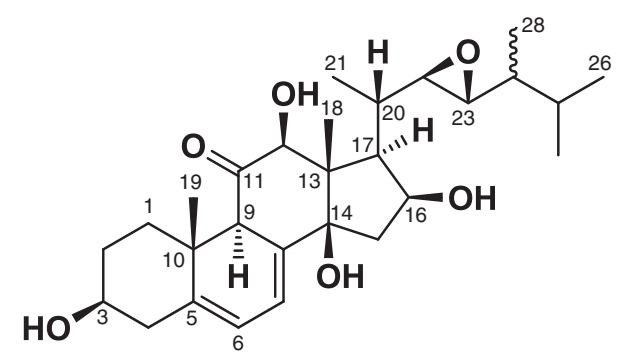

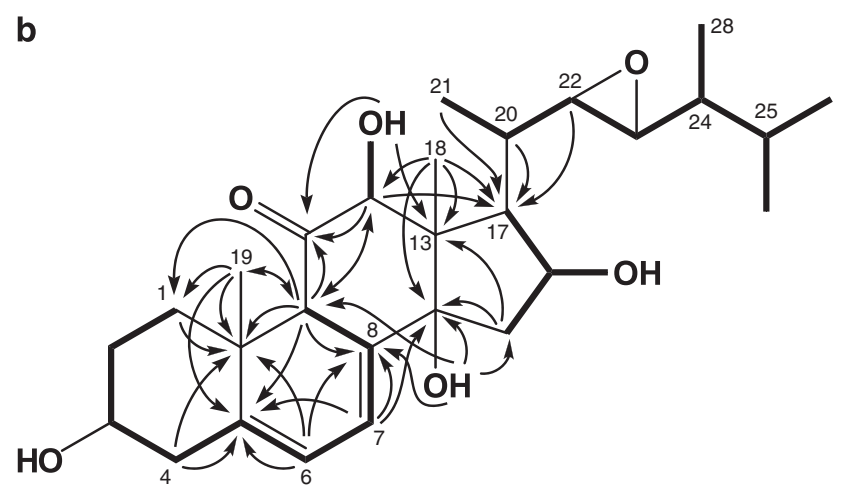

C

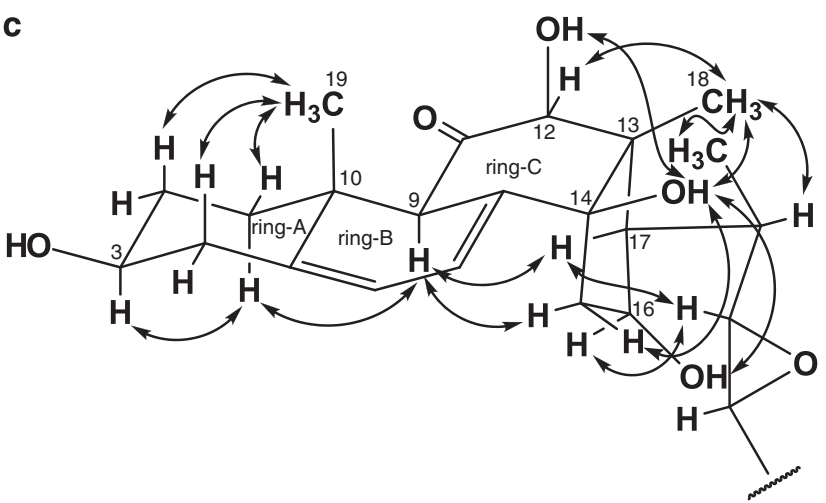

Figure 1 (a) Structure of 1 . (b) Key correlations of ${ }^{1} \mathrm{H}-{ }^{1} \mathrm{H}$ double-quantum-filtered-COSY (bold line) and heteronuclear multiple bond correlation (arrow, proton to carbon) of $\mathbf{1}$. (c) Rotating-frame Overhauser enhancement spectroscopy correlations of 1.

double-quantum-filtered-COSY spectrum, together with a constant time-heteronuclear multiple bond correlation ${ }^{6}$ spectrum as follows:

The sequence from methylene protons $1-\mathrm{H}\left(\delta_{\mathrm{H}} 2.03,1.55\right)$ to a methine proton $9-\mathrm{H}\left(\delta_{\mathrm{H}} 3.06\right)$ through methylene protons $2-\mathrm{H}\left(\delta_{\mathrm{H}}\right.$ $1.93,1.52)$, an oxymethine proton $3-\mathrm{H}\left(\delta_{\mathrm{H}} 3.70\right)$, methylene protons $4-\mathrm{H}\left(\delta_{\mathrm{H}} 2.52,2.27\right)$, two olefinic protons $6-\mathrm{H}\left(\delta_{\mathrm{H}} 6.33\right)$ and $7-\mathrm{H}\left(\delta_{\mathrm{H}}\right.$ 5.77) including allylic couplings between $4-\mathrm{H}$ and $6-\mathrm{H}$ and between $7-$ $\mathrm{H}$ and $9-\mathrm{H}$ was established as shown in Figure $1 \mathrm{~b}$. The ${ }^{1} \mathrm{H}-{ }^{13} \mathrm{C}$ correlations from a methyl proton $19-\mathrm{H}\left(\delta_{\mathrm{H}} 0.89\right)$ to a methylene carbon C-1 $\left(\delta_{\mathrm{C}} 37.9\right)$, an olefinic carbon C-5 $\left(\delta_{\mathrm{C}} 140.1\right)$, a methine carbon C-9 $\left(\delta_{\mathrm{C}} 56.8\right)$ and a quaternary carbon C-10 $\left(\delta_{\mathrm{C}} 38.4\right)$ observed in the heteronuclear multiple bond correlation spectrum of 1 revealed a 9-methyldecalin-2,4(10)-dien-6-ol structure (Figure $1 \mathrm{~b})$. The sequence from a methyl proton $21-\mathrm{H}\left(\delta_{\mathrm{H}} 1.18\right)$ to a methyl proton $26-\mathrm{H}\left(\delta_{\mathrm{H}} 0.98\right)$ through a methine proton $20-\mathrm{H}\left(\delta_{\mathrm{H}}\right.$ $1.67)$, two epoxy protons $22-\mathrm{H}\left(\delta_{\mathrm{C}} 62.0, \delta_{\mathrm{H}} 2.80\right)$ and $23-\mathrm{H}\left(\delta_{\mathrm{C}} 61.4\right.$, $\left.\delta_{\mathrm{H}} 2.90\right)$, a methine proton $24-\mathrm{H}\left(\delta_{\mathrm{H}} 1.34\right)$ and a methine proton $25-$ $\mathrm{H}\left(\delta_{\mathrm{H}} 1.83\right)$, together with spin couplings between $24-\mathrm{H}$ and a methyl proton $28-\mathrm{H}\left(\delta_{\mathrm{H}} 0.96\right)$ and between $25-\mathrm{H}$ and a methyl proton $27-\mathrm{H}$ $\left(\delta_{\mathrm{H}} 0.94\right)$, established a 3,4-epoxy-5,6-dimethylhept-2-yl substructure (Figure $1 \mathrm{~b}$ ). The presence of an oxacyclopropane ring at the positions of C-22 and C-23 was determined by their characteristic ${ }^{13} \mathrm{C}$ shifts, and its stereochemistry was determined to be cis by their coupling constant $(J=4.4 \mathrm{~Hz})$. In a similar manner, ${ }^{1} \mathrm{H}-{ }^{1} \mathrm{H}$ spin couplings for two fragment structures-a hydroxymethine at C-12 $\left(\delta_{\mathrm{H}} 4.10 ; \mathrm{OH}: \delta_{\mathrm{H}}\right.$ $3.49)$ and a 2-hydroxypropane composed of $15-\mathrm{H}\left(\delta_{\mathrm{H}} 1.73,1.62\right)$ through $16-\mathrm{H}\left(\delta_{\mathrm{H}} 4.38\right.$; OH: $\left.\delta_{\mathrm{H}} 4.11\right)$ to $17-\mathrm{H}\left(\delta_{\mathrm{H}} 1.53\right)$-were observed as shown in Figure 1b. Long-range couplings from the two methine protons $9-\mathrm{H}$ and $12-\mathrm{H}$ and from the hydroxyl proton $12-\mathrm{OH}$ to a carbonyl carbon $\mathrm{C}-11\left(\delta_{\mathrm{C}} 214.7\right)$; from a methyl proton $18-\mathrm{H}\left(\delta_{\mathrm{H}}\right.$ $1.37)$ to two methine carbons $\mathrm{C}-12\left(\delta_{\mathrm{C}} 84.3\right)$ and $\mathrm{C}-17\left(\delta_{\mathrm{C}} 53.6\right)$ and to two quaternary carbons $\mathrm{C}-13\left(\delta_{\mathrm{C}} 58.1\right)$ and $\mathrm{C}-14\left(\delta_{\mathrm{C}} 83.7\right)$; and from a hydroxyl proton $14-\mathrm{OH}\left(\delta_{\mathrm{H}} 4.48\right)$ to $\mathrm{C}-8\left(\delta_{\mathrm{C}} 132.5\right), \mathrm{C}-14$ and a methylene carbon $\mathrm{C}-15\left(\delta_{\mathrm{C}} 44.2\right)$ elucidated the connectivity among the three substructures, decalin, hydroxymethine and hydroxypropane, in the steroid nucleus. Finally, the remaining 3,4-epoxy-5,6dimethylhept-2-yl substructure was determined to be attached to C-17 as revealed by ${ }^{1} \mathrm{H}-{ }^{13} \mathrm{C}$ long-range couplings from $20-\mathrm{H}, 21-\mathrm{H}$ and $22-$ $\mathrm{H}$ to $\mathrm{C}-17$. Thus, the planar structure of $\mathbf{1}$ was determined as shown in Figure 1a.

Relative configuration was assigned on the basis of coupling constants and the analysis of a rotating-frame Overhauser enhancement 
Table $1{ }^{13} \mathrm{C}$ and ${ }^{1} \mathrm{H}$ NMR data for 1

\begin{tabular}{|c|c|c|}
\hline & $\delta_{C}$ & $\delta_{H}$ (multiplicity, J in $\mathrm{Hz}$ ) \\
\hline 1 & 37.9 & $2.03(\mathrm{dt}, 13.2,3.1) ; 1.55(\mathrm{~m})$ \\
\hline 2 & 31.3 & $1.93(\mathrm{~m}) ; 1.52(\mathrm{~m})$ \\
\hline 3 & 70.1 & $3.70(\mathrm{~m})$ \\
\hline 4 & 40.2 & $\begin{array}{l}2.52 \text { (ddd, 14.6, 4.5, 2.3); } \\
2.27 \text { (br d, 13.0) }\end{array}$ \\
\hline 5 & 140.1 & \\
\hline 6 & 119.6 & $6.33(\mathrm{dd}, 5.8,2.7)$ \\
\hline 7 & 119.9 & $5.77(\mathrm{dd}, 5.8,2.4)$ \\
\hline 8 & 132.5 & \\
\hline 9 & 56.8 & 3.06 (br s) \\
\hline 10 & 38.4 & \\
\hline 11 & 214.7 & \\
\hline 12 & 84.3 & $4.10(d, 4.7)$ \\
\hline 13 & 58.1 & \\
\hline 14 & 83.7 & \\
\hline 15 & 44.2 & $1.73(\mathrm{br} \mathrm{d}, 14.2) ; 1.62(\mathrm{~m})$ \\
\hline 16 & 75.8 & $4.38(\mathrm{dt}, 3.4,2.9)$ \\
\hline 17 & 53.6 & $1.53(\mathrm{~m})$ \\
\hline 18 & 20.13 & $1.37(\mathrm{~s})$ \\
\hline 19 & 18.2 & $0.89(\mathrm{~s})$ \\
\hline 20 & 30.4 & $1.67(\mathrm{~m})$ \\
\hline 21 & 17.6 & 1.18 (d-like, 6.6) \\
\hline 22 & 62.0 & $2.80(\mathrm{dd}, 9.6,4.4)$ \\
\hline 23 & 61.4 & $2.90(\mathrm{dd}, 9.8,4.4)$ \\
\hline 24 & 36.4 & $1.34(\mathrm{~m})$ \\
\hline 25 & 31.1 & 1.83 (septet of doublet, $6.9,4.4$ ) \\
\hline 26 & 20.07 & $0.98(d, 7.1)$ \\
\hline 27 & 18.1 & $0.94(d, 6.8)$ \\
\hline 28 & 12.7 & $0.96(d, 6.8)$ \\
\hline $12-\mathrm{OH}$ & & $3.49(\mathrm{~d}, 4.9)$ \\
\hline $14-\mathrm{OH}$ & & $4.48(\mathrm{~s})$ \\
\hline $16-\mathrm{OH}$ & & $4.11(\mathrm{br} \mathrm{s})$ \\
\hline
\end{tabular}

NMR spectra were measured on a Varian NMR system 500 NB CL (Varian, Palo Alto, CA, USA) in chloroform- $d$ with the residual solvent peak as an internal standard $\left(\delta_{\mathrm{C}} 77.0, \delta_{\mathrm{H}}\right.$ 7.26 p.p.m.).

spectroscopy experiment. The large coupling constants for $J_{2 \beta \mathrm{H}, 3 \mathrm{H}}$ $(11.0 \mathrm{~Hz})$ and $J_{3 \mathrm{H}, 4 \mathrm{BH}}(11.0 \mathrm{~Hz})$ and for the rotating-frame Overhauser enhancement spectroscopy correlations (Figure 1c) between $1-\alpha \mathrm{H}$ and $3-\mathrm{H}$; between $2-\beta \mathrm{H}$ and $19-\mathrm{H}$; and between $4-\beta \mathrm{H}$ and $19-\mathrm{H}$ indicated that ring-A should be in a chair conformation with the hydroxyl groups at $\mathrm{C}-3$ in $\beta$-equatorial orientation and with the methyl group (C-19) at C-10 in $\beta$-axial orientation. On the other hand, the rotatingframe Overhauser enhancement spectroscopy correlations between $1-\alpha \mathrm{H}$ and 9-H; between $9-\mathrm{H}$ and $15-\alpha \mathrm{H}$; and between $9-\mathrm{H}$ and $17-\alpha \mathrm{H}$ revealed that the ring junction proton $9-\mathrm{H}$ is located in $\alpha$-axial orientation. Further, the rotating-frame Overhauser enhancement spectroscopy correlations between $12-\mathrm{H}$ and $18-\mathrm{H}$; between $12-\mathrm{OH}$ and $14-\mathrm{OH}$; between $14-\mathrm{OH}$ and $18-\mathrm{H}$; between $14-\mathrm{OH}$

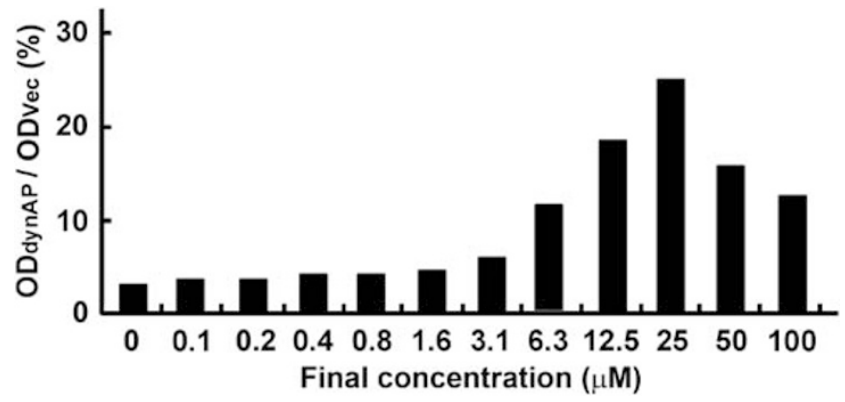

Figure 2 Recovery of the dynAP-induced growth inhibition of Mad2-lacking mutant yeast by 1 . Exponentially growing Mad2-lacking mutant cells harboring the empty vector or dynAP expression vector were washed and adjusted for their cell density, followed by incubation in galactose medium containing 1 in DMSO or DMSO alone. After $48 \mathrm{~h}$, growth recoveries were calculated by measuring the OD of cell cultures. $O D_{\mathrm{vec}}$ is $\mathrm{OD}$ of mutant cells harboring the empty vector treated with DMSO. OD dynAP $_{\text {is }} \mathrm{OD}$ of dynAPexpressed mutant treated with $\mathbf{1}$.

and $15-\beta \mathrm{H}$; between $14-\mathrm{OH}$ and $16-\mathrm{OH}$; between $18-\mathrm{H}$ and $20-\mathrm{H}$; and between $18-\mathrm{H}$ and $21-\mathrm{H}$ revealed that the three hydroxyl groups at $\mathrm{C}-12, \mathrm{C}-14$ and $\mathrm{C}-16$, the methyl group (C-18) at $\mathrm{C}-13$ and the side chain at $\mathrm{C}-17$ are in $\beta$-orientation, but that of $\mathrm{C}-28$ was not determined. Thus, the structure of 1 was established as $(3 \beta, 12 \beta, 14 \beta, 16 \beta)-22,23$-epoxy-3,12,14,16-tetrahydroxyergosta-5,7-dien11-one (Figure 1).

Compound 1 restored the dynAP-induced growth inhibition of Mad2-lacking mutant yeast at a concentration of $25 \mu \mathrm{M}$ (Figure 2). Furthermore, compounds related to 1 induced dynAP-mediated Golgi fragmentation and apoptosis in human cancer cells. ${ }^{5}$ Thus, 1 may serve as an important compound for developing anticancer drugs and also as a valuable tool for conducting studies on the action mechanism of dynAP. The detailed biological activity and the structure-activity relationship of 1 will be reported elsewhere. ${ }^{5}$

\section{ACKNOWLEDGEMENTS}

This study was supported by a grant from the New Energy and Industrial Technology Department Organization (NEDO) of Japan.

1 Moorthamer, M., Panchal, M., Greenhalf, W. \& Chaudhuri, B. The p16(INK4A) protein and flavopiridol restore yeast cell growth inhibited by Cdk4. Biochem. Biophys. Res. Commun. 250, 791-799 (1998).

$2 \mathrm{Cid}, \mathrm{V}$. J. et al. Assessment of PTEN tumor suppressor activity in nonmammalian models: the year of the yeast. Oncogene 27, 5431-5442 (2008).

3 Perkins, E. et al. Novel inhibitors of poly(ADP-ribose) polymerase/PARP1 and PARP2 identified using a cell-based screen in yeast. Cancer Res. 61, 4175-4183 (2001).

4 Simon, J. A. \& Bedalov, A. Yeast as a model system for anticancer drug discovery. Nature Rev. Cancer 4, 481-492 (2004).

5 Kunoh, T. et al. Identification of a novel human dynactin-associating protein, dynAP, and chemicals that induce dynAP-mediated apoptotic cell death (In submission).

6 Furihata, K. \& Seto, H. Constant time HMBC (CT-HMBC), a new HMBC technique useful for improving separation of cross peaks. Tetrahedron Lett. 39, 7337-7340 (1998). 